\title{
Influence of epipregnanolone on the modulation
} of rapid tolerance to ethanol by neurosteroids \begin{tabular}{l} 
Influência da epipreginanolona sobre a modulação da \\
tolerância rápida ao etanol pelos neuroesteróides \\
\hline
\end{tabular}

Adriana Dias Elpo Barbosa, ${ }^{1}$ Gina Struffaldi Morato $^{2}$

Abstract

Objective: The objective of the present study was to investigate the effect of epipregnanolone on the influence of neurosteroids on the development of rapid tolerance to the motor impairing and hypothermic effects of ethanol. Method: Experiment 1: on Day 1 groups of mice were pretreated with saline or with epipregnanolone. After 30 min each group was further divided in subgroups that received ethanol or saline. Thirty, 60 and 90 min after the injections the animals were tested on the rota-rod or the body temperature was measured. On Day 2 all groups received ethanol and a similar procedure was followed to evaluate rapid tolerance. Experiment 2 and 3: On Day 1 groups of mice were treated with epipregnanolone and after 15 min each group was divided into three groups in order to receive pregnenolone sulfate, dehydroepiandrosterone sulfate or saline. Thirty minutes later, each group was further divided into two subgroups in order to receive ethanol or saline, respectively, and 30, 60 and 90 min later the animals were tested as in the experiment 1. On Day 2 all groups received ethanol and a similar procedure was followed to evaluate rapid tolerance. Results: Pretreatment with epipregnanolone $(0.10-0.30 \mathrm{mg} / \mathrm{kg})$ significantly blocked the development of tolerance to the motor impairing and hypothermic effects induced by ethanol in mice. Considering tolerance to ethanolinduced motor impairment, epipregnanolone $(0.15 \mathrm{mg} / \mathrm{kg}$ ) reversed the stimulatory action of dehydroepiandrosterone sulfate $(0.15 \mathrm{mg} / \mathrm{kg})$, but did not affect the actions of pregnenolone sulfate $(0.08 \mathrm{mg} / \mathrm{kg})$. Moreover, epipregnanolone prevented the inhibitory action of allotetrahydrodeoxycorticosterone $(0.10 \mathrm{mg} / \mathrm{kg}$ ). In relation to ethanol-induced hypothermia, the results showed that pretreatment with epipregnanolone $(0.30 \mathrm{mg} / \mathrm{kg}$ ) significantly prevented the stimulatory action of dehydroepiandrosterone sulfate and pregnenolone sulfate, as well as the inhibitory action of allotetrahydrodeoxicorticosterone $(0.20 \mathrm{mg} / \mathrm{kg}$ ), on tolerance to this effect. Conclusions: The results suggest a differential interaction between neurosteroids that might modulate the development of rapid tolerance to ethanol.

\section{Descriptors: Drug tolerance; Ethanol; Neurologic manifestations; Steroids; Hypothermia}

\section{Resumo}

Objetivo: O objetivo do presente estudo foi o de investigar o efeito da epipregnanolona sobre a influência de neuroesteróides no desenvolvimento da tolerância rápida aos efeitos de incoordenação motora e hipotermia induzidos pelo etanol. Método: Experimento 1: no Dia 1, grupos de camundongos foram pré-tratados com salina ou com epipregnanolona. Após 30 min, cada grupo foi subdividido recebendo etanol ou salina. Aos 30, 60 e 90 min após as injeções, os animais foram testados no rota-rod ou a temperatura corporal foi avaliada. No Dia 2, todos os grupos receberam etanol e um procedimento similar foi seguido para avaliar a tolerância rápida. O pré-tratamento com a epipregnanolona $(0,10-0,30 \mathrm{mg} / \mathrm{kg})$ bloqueou significantemente o desenvolvimento da tolerância aos efeitos de incoordenação motora e hipotermia induzidos pelo etanol em camundongos. Experimento 2 e 3: no Dia 1, grupos de animais foram tratados com epipregnanolona e, após $15 \mathrm{~min}$, cada grupo foi dividido em três grupos para receber sulfato de pregnanolona, sulfato de dehidroepiandrosterona ou salina. Após 30 min, cada grupo foi dividido em dois subgrupos para receber etanol ou salina, respectivamente, e após 30, 60 e 90 min os animais foram testados como no experimento 1. No Dia 2, todos os grupos receberam etanol e 30 min após foram testados como mencionado no experimento 1. Resultados: Considerando a tolerância ao prejuízo motor induzido pelo etanol, a epipregnanolona (0,15 mg/kg) bloqueou a ação estimulatória do sulfato de dehidroepiandrosterona $(0,15 \mathrm{mg} / \mathrm{kg})$, mas não afetou a ação do sulfato de pregnanolona $(0,08 \mathrm{mg} / \mathrm{kg})$. Entretanto, a epipregnanolona bloqueou a ação inibitória da alotetrahidrodeoxicorticosterona $(0,10 \mathrm{mg} / \mathrm{kg})$. Em relação à hipotermia induzida pelo etanol, os resultados demonstraram que o pré-tratamento com epipregnanolona $(0,30 \mathrm{mg} / \mathrm{kg}$ ) bloqueou significantemente a ação estimulatória do sulfato de dehidroepiandrosterona e do sulfato de pregnanolona, bem como a ação inibitória da alotetrahidrodeoxicorticosterona $(0,20 \mathrm{mg} / \mathrm{kg})$ sobre a tolerância. Conclusões: Os resultados sugerem uma interação diferencial entre os neuroesteróides sobre o desenvolvimento da tolerância rápida ao etanol.

Descritores: Tolerância a drogas; Etanol; Manifestações neurológicas; Esteróides; Hipotermia

\footnotetext{
1 Coordenadoria de Medicina/CCS, Universidade do Vale do Itajaí (Univali), Itajaí (SC), Brasil

2 Departamento de Farmacologia, Centro de Ciências Biológicas, Universidade Federal de Santa Catarina (UFSC), Florianópolis (SC), Brasil

Financing: This study was supported by the Conselho Nacional de Desenvolvimento Científico e Tecnológico (CNPq) - Grant 520654/960 BF

Conflict of interests: A.D.E.B. had a scholarship from CNPq.

G.S.M. is a research fellow of CNPq, Brazil

Submitted: December 11, 2006

Accepted: May 30, 2007

\section{Correspondence}

Adriana Dias Elpo Barbosa

Coordenadoria de Medicina, Centro de Ciências da Saúde, Universidade do Vale do Itajaí

Rua Uruguai, 458

89302-202 Itajaí, SC, Brasil

Phone: (55 47) 34 1-7678 Fax: (55 47) 34 1-7865

e-mail: adrielpo@univali.br; adrielpo@bol.com.br
} 


\section{Introduction}

Several neuroactive steroids exhibit rapid, non-genomic activity in the central nervous system. Their rapid mechanisms of action include modulation of N-methyl-D-aspartate (NMDA) and $\boldsymbol{\gamma}$-aminobutyric acid type A (GABA-A) receptor activity. ${ }^{1,2}$ Studies have shown that positive or negative allosteric modulators of the NMDA receptor complex bind to distinct sites on this receptor and these sites are different from the glycine, dizocilpine (MK-801), $\mathrm{Mg}^{2+}$ and spermine sites. ${ }^{3}$ Furthermore, pregnenolone sulfate and dehydroepiandrosterone sulfate, which are negative allosteric modulators of the GABAA receptor, act non-competitively to reduce the activity of GABAA and glycine receptors, ${ }^{4,5}$ whereas androsterone, progesterone, allotetrahydrodeoxycorticosterone, allopregnanolone, pregnanolone, and epipregnanolone act as positive allosteric modulators at the GABA-A receptor. 6,7 An action related to the inhibition of voltage-operated calcium channels has also been described for neurosteroids. ${ }^{8}$

Recently, increasing evidence has shown a role for neurosteroids in the effects of ethanol. ${ }^{9,10}$ It was demonstrated that allopregnanolone decreased the latency and increased the sleeping time induced by ethanol, whereas pregnenolone sulfate and dehydroepiandrosterone sulfate reduced the duration of sleep. ${ }^{11}$ Moreover, ethanol was shown to induce a dose-dependent augmentation of allopregnanolone blood levels in rats. ${ }^{9}$

Knowledge of the phenomenon of tolerance to the effects of ethanol has helped our understanding of the underlying nature of alcohol addiction and has prompted the development of new schemes for the treatment of this disease. Tolerance to ethanol can promote an attenuation of the aversive effect of this drug with regard to its rewarding effects, usually leading to increased beverage consumption. ${ }^{12}$ This relevant component of alcohol dependence has been studied with respect to its development in time. Acute tolerance is observed during the course of a single ethanol administration, whereas chronic tolerance is generally detected after several days, weeks or months of repeated ethanol administrations. ${ }^{12,13}$ Rapid tolerance, which is usually detected between eight and twenty-four hours after a first injection of ethanol,14,15 has been considered as a reliable predictor of chronic tolerance. This is due to the fact that similar results were obtained with rapid and chronic paradigms in studies involving ethanol and other drugs. ${ }^{16}$

The mechanism through which ethanol affects central nervous system function involves several neurotransmitter systems such as amino acids, monoamines, acetylcholine, opioid peptides, nitric oxide, and neuroactive steroids. ${ }^{13,17}$ Some studies have shown that glutamatergic neurotransmission (mainly at NMDA receptors) can be blocked, whereas GABAergic neurotransmission can be stimulated by ethanol. ${ }^{13}$ Moreover, the NMDA receptor complex seems to participate in the development of tolerance to ethanol. ${ }^{14,18-20}$

Our previous study showed that the negative GABA-A receptor modulators pregnenolone sulfate and dehydroepiandrosterone sulfate stimulated, whereas the positive GABA-A receptor modulator epipregnanolone blocked the development of chronic tolerance to the incoordinating effect of ethanol. ${ }^{21}$ Other evidence suggests that the pretreatment with pregnenolone sulfate and dehydroepiandrosterone sulfate facilitated tolerance to the motor impairment produced by ethanol. ${ }^{21}$ Moreover, in vitro studies have shown that epipregnanolone antagonizes the effects of some neurosteroids with positive influence on GABA-A receptors. ${ }^{6}$ Thus, the understanding of the interaction between different neurosteroids in the modulation of the phenomenon of tolerance to ethanol may contribute to the development of potential therapeutic alternative for the treatment of alcoholism. The objective of the present study was to investigate the effects of an interaction between neurosteroids in the modulation of tolerance to two effects of ethanol: motor incoordination and hypothermia, using the rapid tolerance paradigm. ${ }^{15,16,23}$ This study was performed at the Departamento de Farmacologia da Universidade Federal de Santa Catarina.

\section{Method}

\section{Animals}

Adult male Swiss mice from Universidade Federal de Santa Catarina's colony were used, with an age range between two and two and a half months and weighing between $25 \mathrm{~g}$ and $30 \mathrm{~g}$. The animals were bred at the university's animal house and transferred to our department's facilities at least two weeks prior to use, where they were housed in groups of 20 in plastic cages (42 cm x $34 \mathrm{~cm} \times 17 \mathrm{~cm}$ ), and maintained at $23 \pm 1^{\circ} \mathrm{C}$ under artificial illumination (lights on between 6 am and 6 pm) with standard laboratory chow and tap water ad libitum. All experiments were conducted between 1300 and 1730 hours in order to minimize circadian influences, and all animals were naive to drug treatment and experience. All procedures were approved by our institutional ethics committee (CEUA No. 058/2001).

\section{Drugs}

Analytical grade ethanol was purchased from Merck Laboratory (Darmstadt, Germany). Pregnenolone sulfate (5-pregnen-3 $\beta$ ol-20-one sulfate sodium) and dehydroepiandrosterone sulfate (5-androsten-3ß-ol-17-one sulfate sodium) were obtained from Research Biochemicals International (Natick, USA). Epipregnanolone (5 $\beta$-pregnan-3 $\beta$-ol-20-one) and allotetrahydrodeoxycorticosterone ( $5 \alpha$-pregnane-3 $\alpha$, 21-diol-20one) were obtained from Sigma Chemical Co. (Saint Louis, USA). Ethanol, pregnenolone sulfate and dehydroepiandrosterone sulfate were prepared in $0.9 \% \mathrm{NaCl}$ (saline). Ethanol was diluted to the concentration of $14 \% \mathrm{w} / \mathrm{v}$. Epipregnanolone and allotetrahydrodeoxycorticosterone were dissolved in a solution of $1 \%$ polyoxyethylenesorbitan monooleate (Tween 80; Sigma Chemical Co., Saint Louis, USA) in saline. All solutions were freshly prepared and administered by the intraperitoneal route (i.p.). All volumes injected were of $1 \mathrm{ml} / \mathrm{kg}$ body weight except for ethanol that was adjusted according to the dose used.

\section{Motor impairment test}

Motor impairment was measured on a rota-rod apparatus (Rotamex-V-EE/85) controlled by a computational system (Columbus Instruments Computer-Counter Interface; Ohio, USA), where animals were trained under continuous acceleration (1 rpm/s) in 1 -min sessions. Whenever a mouse dropped off the rotating bar, it received a foot shock (0.1 mA for 2 seconds) and was then returned to its cage. The latency (in seconds) to fall off the rotating bar (which corresponded to the rotational velocity at which the animal dropped off the rotating bar) was taken as the performance score. Mice that did not reach a stable baseline (i.e. at least $20 \mathrm{~s}$ ) in 10 trials were discarded. Animals that presented performances between 20-40 s were chosen for the experiment. The percentage of animals that usually attained the criterion was $92 \%$. After the selection, experimental and control groups were matched based on both 
body weight and mean performance during the last training sessions on the rota-rod. With this procedure, animals presented similar basal values in all groups. The test score was the score obtained by each mouse at 30,60 or 90 minutes after ethanol (or control) injections. The motor incoordination was usually most severe at 30 minutes following the injections. The lowest test score obtained in each test session was used to calculate the maximum percent of motor impairment, according to the formula:

Maximum \% of motor impairment $=[$ (baseline score)-(test score) / (baseline score)] x 100

\section{Hypothermia test}

Body temperature was determined by a Thermistor thermometer (Model 8402-00) provided with a probe lubricated with vaseline that was inserted $2.5 \mathrm{~cm}$ into the rectum and left in place until a stable temperature recording was obtained (approximately 30 s). Temperature was taken prior to and at 30,60 and 90 minutes after the injections. The values were expressed as the difference between one measurement and the respective basal temperature for each animal (maximum difference).

\section{Experimental procedure}

Experiment 1 - Effect of epipregnanolone on the development of rapid tolerance to ethanol (rota-rod and hypothermia tests). In order to investigate whether epipregnanolone could block tolerance to the motor impairing effect of alcohol, on Day 1 three groups of previously trained mice were pretreated with saline and three other groups were pretreated with epipregnanolone $(0.05,0.10$ or $0.15 \mathrm{mg} / \mathrm{kg})$. Thirty minutes later, each group was further divided into two subgroups to receive ethanol $(2.25 \mathrm{~g} / \mathrm{kg})$ or saline, respectively. The number of animals per group was 10 . Thirty, 60 and 90 minutes after the injections, the animals were tested on the rota-rod. The animals were then returned to their home cages. On Day 2, all groups, including controls, received ethanol $(2.25 \mathrm{~g} / \mathrm{kg})$, and at 30,60 and 90 minutes the animals were tested on the rota-rod to evaluate rapid tolerance. This dose of alcohol was chosen because it has been shown to produce a clear, rapid tolerance. ${ }^{22}$
To study the influence of epipregnanolone on tolerance to the hypothermic effect of ethanol, on Day 1 two groups of mice were pretreated with saline and two further groups received epipregnanolone $(0.15 \mathrm{mg} / \mathrm{kg}$ or $0.30 \mathrm{mg} / \mathrm{kg}$, respectively). After 30 minutes, each group was further divided in two subgroups that received ethanol $(4.0 \mathrm{~g} / \mathrm{kg}$ ) or saline. The hypothermic response was measured before and at 30, 60 and 90 minutes after the last injections. The animals were then returned to their home cages. On Day 2 , the animals' basal body temperatures were taken. Then, a challenge dose of $2.0 \mathrm{~g} / \mathrm{kg}$ ethanol was administered to all animals, and the measurement of body temperatures was repeated 30, 60 and 90 minutes later. A previous study has shown that this dose of ethanol produces a clear and reliable rapid tolerance to ethanol hypothermia. ${ }^{24}$

Experiment 2 - Rota-rod test: effect of epipregnanolone on the facilitation of rapid tolerance to ethanol by pregnenolone sulfate and dehydroepiandrosterone sulfate, and on the blockade of rapid tolerance by allotetrahydrodeoxycorticosterone. On Day 1 , two groups of mice were treated with epipregnanolone $(0.15$ or $0.30 \mathrm{mg} / \mathrm{kg}$ ) and after 15 minutes each group was divided into two groups in order to receive pregnenolone sulfate $(0.08 \mathrm{mg} / \mathrm{kg})$ or saline, respectively. Thirty minutes later, each group was further divided into two subgroups in order to receive ethanol $(1.9 \mathrm{~g} / \mathrm{kg})$ or saline, respectively. Thirty, 60 and 90 minutes later the animals were tested on the rota-rod, as in the previous experiment. On Day 2, all groups including controls received ethanol $(1.9 \mathrm{~g} / \mathrm{kg})$, and 30 minutes later they were tested on the rota-rod to evaluate rapid tolerance. In other groups of animals, a similar procedure was followed, except that dehydroepiandrosterone sulfate at a dose of $0.15 \mathrm{mg} / \mathrm{kg}$ was used instead of pregnenolone sulfate. This dose of ethanol $(1.9 \mathrm{~g} / \mathrm{kg}$ ) has been shown not to produce rapid tolerance per se in the rota-rod test. ${ }^{22}$

Two other groups of mice, on Day 1 , were treated with epipregnanolone $(0.15$ or $0.30 \mathrm{mg} / \mathrm{kg}$ ) and after 15 minutes each group received allotetrahydrodeoxicorticosterone $(0.10$ $\mathrm{mg} / \mathrm{kg}$ ) or saline, respectively. Thirty minutes later, each group was further divided into two subgroups in order to
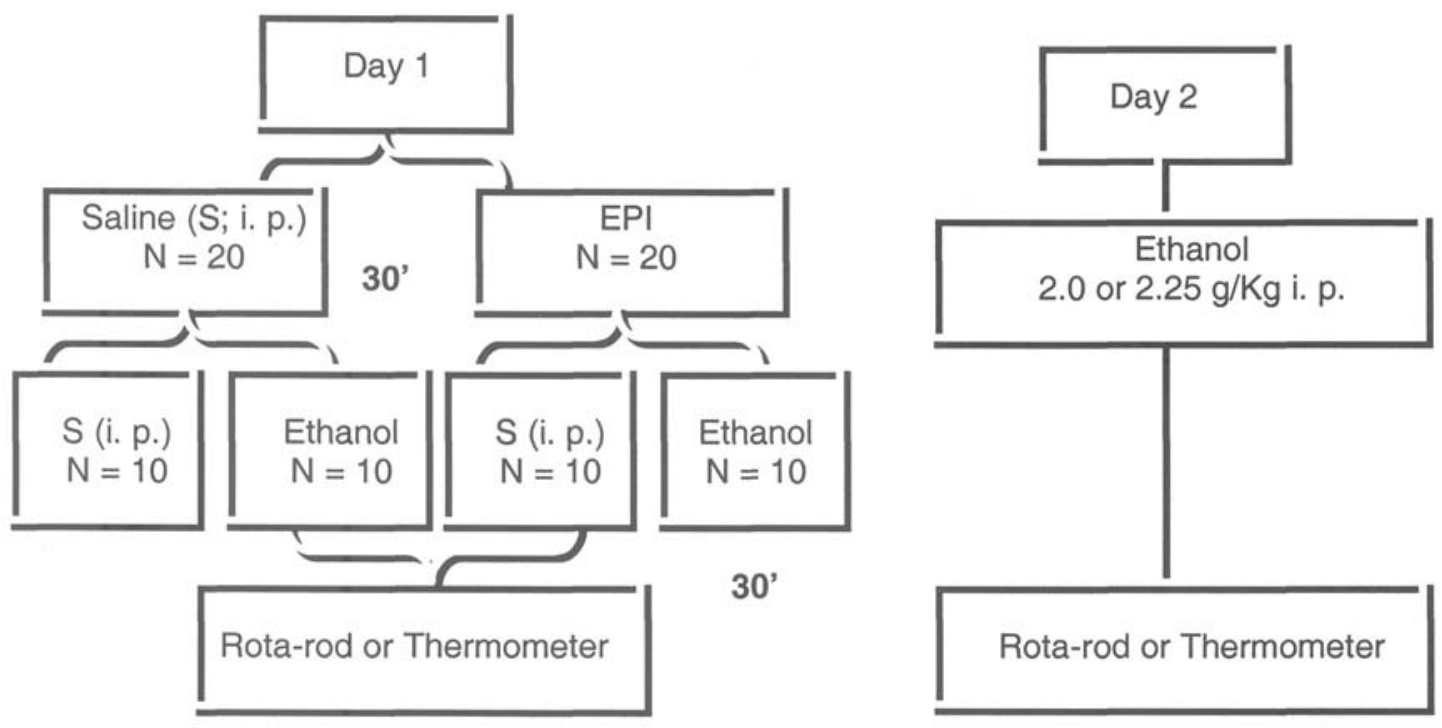

Figure 1 - Effect of epipregnanolone (EPI) on the development of rapid tolerance to the motor impairing and hypothermic effects of ethanol 
receive ethanol $(2.25 \mathrm{~g} / \mathrm{kg})$ or saline. Thirty, 60 and 90 minutes later the animals were tested on the rota-rod, before being returned to their home cages. On Day 2, all groups including controls received ethanol $(2.25 \mathrm{~g} / \mathrm{kg})$, and 30 minutes later they were tested on the rota-rod to evaluate rapid tolerance.

Experiment 3 - Hypothermia test: effect of epipregnanolone on the facilitation of rapid tolerance to ethanol by pregnenolone sulfate and dehydroepiandrosterone sulfate, and on the blockade of rapid tolerance by allotetrahydrodeoxycorticosterone. For the hypothermia experiment, a similar protocol as in the previous experiment was followed, except that on Day 1 mice were pretreated only with epipregnanolone $(0.30 \mathrm{mg} / \mathrm{kg})$, and treated with $4.0 \mathrm{~g} / \mathrm{kg}$ ethanol. The dose of pregnenolone sulfate was $0.15 \mathrm{mg} / \mathrm{kg}$ and of dehydroepiandrosterone sulfate was $0.20 \mathrm{mg} / \mathrm{kg}$. The hypothermic response was measured at 30, 60 and 90 minutes after ethanol administration. The animals were then returned to their home cages. On Day 2, a challenge dose of $2.5 \mathrm{~g} / \mathrm{kg}$ ethanol was administered to the animals and body temperature was again measured after 30, 60 and 90 min. This dose of ethanol was shown in preliminary experiment not to produce rapid tolerance to hypothermia per se (Barbosa and Morato, 2002).

Two further groups of mice, on Day 1 , were treated with epipregnanolone $(0.30 \mathrm{mg} / \mathrm{kg})$ or saline, and after 15 minutes each group was divided in order to receive allotetrahydrodeoxycorticosterone $(0.20 \mathrm{mg} / \mathrm{kg})$ or saline, respectively. Thirty minutes later, each group was further divided into two subgroups in order to receive ethanol $(4.0 \mathrm{~g} / \mathrm{kg})$ or saline. Thirty, 60 and 90 minutes later the animals' temperature was measured. The animals were returned to their home cages. On Day 2, all groups, including controls, received ethanol $(2.0 \mathrm{~g} / \mathrm{kg})$, and their body temperature was measured at 30 , 60 and 90 minutes.

\section{Statistical analysis}

Statistica ${ }^{\circledR}$ for Windows 4.5 (Statsoft, Inc., Tulsa, OK, USA) and Grap Pad Instat 3.01 (GraphPad Instat Software Inc.) softwares were used to perform the statistical analysis. Maximum percent of motor impairment data were analyzed using a multifactorial analysis of variance with pretreatment, treatment and days as independent variables. Post hoc comparisons were performed using Tukey's test. Shapiro-Wilk's W test and Bartlett's test were used in testing for normality and for homogeneity of variances of data, respectively. Values of $p<0.05$ were considered significant. Figures were drawn using GraphPad Prism ${ }^{\circledR} 1.03$ (GraphPad Software Inc., San Diego CA, www.graphpad.com). Data are presented as the mean \pm standard error of mean (S.E.M.).

\section{Results}

Table 1 shows the significant reduction of motor impairment in all groups that received ethanol on both days without drug pretreatment suggesting the development of rapid tolerance with the dose of $2.25 \mathrm{~g} / \mathrm{kg}$ ethanol. Overall, ANOVA showed an effect for the treatment with ethanol $(F(1.36)=13.40$; $\mathrm{p}<0.001 ; \mathrm{F}(1.36)=15.29 ; \mathrm{p}<0.001 ; \mathrm{F}(1.36)=92.35$; $p<0.001$ ) and the post hoc analysis confirmed the development of rapid tolerance to this drug (Tukey's test). Pretreatment with epipregnanolone before ethanol on Day 1 prevented the reduction of motor impairment caused by ethanol on Day 2. ANOVA showed an effect for pretreatment $(F(1.36)=6.73 ; p<0.001 ; F(1.36)=34.77 ; p<0.001)$, and for day factor $(F(1.36)=19.60 ; p<0.001$; $F(1.36)=37.43 ; p<0.001 ; F(1.36)=196.01$; $p<0.001)$. The post hoc analysis confirmed that epipregnanolone $(0.10$ and $0.15 \mathrm{mg} / \mathrm{kg})$ blocked the development of rapid tolerance, whilst this was not blocked by the pretreatment with the dose of $0.05 \mathrm{mg} / \mathrm{kg}$ (Table 1, Day 2).
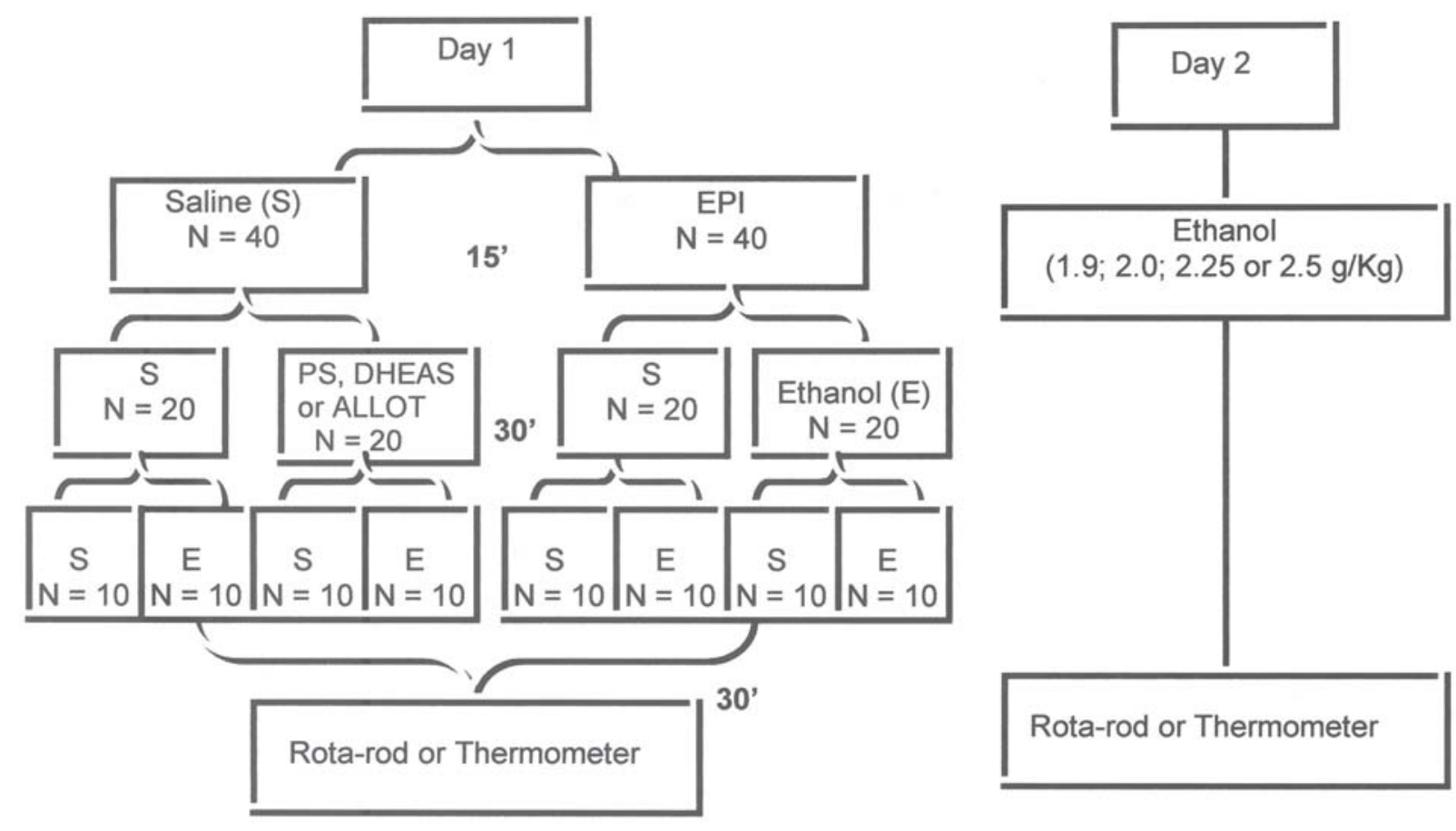

Figure 2 - Effect of epipregnanolone (EPI) on the influence of neurosteroids 
Table 1 - Effect of epipregnanolone on the development of rapid tolerance to the motor impairing and hypothermic effects of ethanol. Results shown are means \pm SD of 10 animals per group

\begin{tabular}{|c|c|c|c|c|}
\hline \multicolumn{5}{|c|}{ Rota-Rod Test } \\
\hline \multicolumn{2}{|c|}{ Treatment } & Day 1 & Day 2 & p-value \\
\hline \multirow[t]{2}{*}{ Saline } & Saline & $14.56 \pm 14.66$ & $67.64 \pm 9.29$ & $p<0.001$ \\
\hline & Ethanol & $68.73 \pm 9.13$ & $44.48 \pm 16.75$ & $p<0.001$ \\
\hline \multirow[t]{2}{*}{ EPI $0.05 \mathrm{mg} / \mathrm{kg}$} & Saline & $17.06 \pm 7.57$ & $68.62 \pm 17.22$ & $p<0.001$ \\
\hline & Ethanol & $67.44 \pm 24.49$ & $46.96 \pm 19.50$ & $p<0.001$ \\
\hline \multirow[t]{2}{*}{ Saline } & Saline & $14.44 \pm 7.39$ & $61.54 \pm 13.24$ & $p<0.001$ \\
\hline & Ethanol & $62.84 \pm 8.15$ & $41.25 \pm 6.13$ & $p<0.001$ \\
\hline EPI $0.10 \mathrm{mg} / \mathrm{kg}$ & Ethanol & $62.22 \pm 14.79$ & $57.16 \pm 24.84$ & $p=0.062$ \\
\hline \multirow[t]{2}{*}{ Saline } & Saline & $14.74 \pm 7.11$ & $63.74 \pm 13.08$ & $p<0.001$ \\
\hline & Ethanol & $62.73 \pm 6.67$ & $42.37 \pm 5.75$ & $p<0.001$ \\
\hline \multirow[t]{2}{*}{ EPI $0.15 \mathrm{mg} / \mathrm{kg}$} & Saline & $16.15 \pm 8.18$ & $72.29 \pm 7.02$ & $p<0.001$ \\
\hline & Ethanol & $73.43 \pm 5.47$ & $68.39 \pm 7.43$ & $p=0.087$ \\
\hline \multicolumn{5}{|c|}{ Temperature Test } \\
\hline Saline & Saline & $0.33 \pm 0.47$ & $1.52 \pm 0.54$ & $p<0.001$ \\
\hline \multirow[t]{2}{*}{ EPI $0.15 \mathrm{mg} / \mathrm{kg}$} & Saline & $0.32 \pm 0.38$ & $1.24 \pm 0.37$ & $p<0.001$ \\
\hline & Ethanol & $2.00 \pm 0.41$ & $1.00 \pm 0.38$ & $p=0.029$ \\
\hline \multirow[t]{2}{*}{ Saline } & Saline & $0.46 \pm 0.42$ & $1.52 \pm 0.47$ & $p<0.001$ \\
\hline & Ethanol & $1.87 \pm 0.47$ & $0.55 \pm 0.35$ & $p<0.001$ \\
\hline \multirow[t]{2}{*}{ EPI $0.30 \mathrm{mg} / \mathrm{kg}$} & Saline & $0.39 \pm 0.37$ & $1.31 \pm 0.38$ & $p<0.001$ \\
\hline & Ethanol & $1.98 \pm 0.44$ & $1.37 \pm 0.35$ & $p=0.032$ \\
\hline
\end{tabular}

$E P I=$ Epipregnanolone. $S D=$ Standard deviation.

Considering the hypothermic effect of ethanol, the results showed that the reduction in body temperature measured on Day 2 was significantly less in the groups treated with ethanol on both days without receiving drug pretreatment, suggesting the development of rapid tolerance to this effect of alcohol (Table 1). ANOVA revealed an effect for the treatment with ethanol $(F(1.36)=22.27 ; p<0.001 ; F(1.36)=29.08$; $p<0.001$ ) and the post hoc analysis confirmed the development of rapid tolerance (Tukey's test). The groups pretreated with epipregnanolone $(0.15$ or $0.30 \mathrm{mg} / \mathrm{kg}$ ) before ethanol on Day 1 presented a reduction of hypothermia suggesting the blockade of rapid tolerance evaluated on Day 2. ANOVA also showed an effect for the pretreatment: $F(1.36)=6.28 ; p<0.001$ and the post hoc analysis showed that only $0.30 \mathrm{mg} / \mathrm{kg}$ epipregnanolone significantly blocked the development of tolerance.

The effects of epipregnanolone on the facilitation of rapid tolerance to ethanol-induced motor impairment by pregnenolone sulfate are depicted in Table 2. It can be seen that the control groups treated with ethanol on both days and treated with saline on Day 1 did not present rapid tolerance. This was expected since the $1.9 \mathrm{~g} / \mathrm{kg}$ dose of ethanol is insufficient to induce rapid tolerance by itself (Barbosa and Morato, 2001). Pretreatment with pregnenolone sulfate facilitated the development of rapid tolerance. Both doses of epipregnanolone did not affect this stimulatory action of pregnenolone sulfate on ethanol tolerance. ANOVA revealed an effect for treatment with ethanol $(F(1.72)=172.24$; $p<0.001 ; F(1.72)=150.54 ; p<0.0001)$, for treatment with pregnenolone sulfate $(F(1.72)=13.94 ; p<0.001)$, for pretreatment with epipregnanolone $(F(1.72)=4.95$; $p<0.001)$, day factor $(F(1.72)=135.99 ; p<0.01$; $F(1.72)=306.23 ; p<0.001)$. However, the post hoc analysis revealed that pretreatment with epipregnanolone did not block the stimulatory effect of pregnenolone sulfate on the development of rapid tolerance (Tukey's test).
Conversely, epipregnanolone prevented the facilitation of the development of tolerance to ethanol by dehydroepiandrosterone sulfate (Table 2). The overall ANOVA revealed a significant effect for the treatment with ethanol ( $F$ $(1.72)=239.53 ; p<0.001 ; F(1.72)=253.12$; $p<0.001)$, showing the impairing effect of this drug. There was also an effect for the treatment with dehydroepiandrosterone sulfate $(F(1.72)=12.79$; $p<0.001 ; F(1.72)=4.96 ; p<0.001)$ and for the day factor $(F(1.72)=155.33 ; p<0.001 ; F(1.72)=197.45$; $p<0.001)$. The post hoc analysis confirmed that pretreatment with both doses of epipregnanolone significantly blocked the stimulating effect of dehydroepiandrosterone sulfate on rapid tolerance (Tukey' test).

The results of the evaluation of the effects of epipregnanolone on the influence of allotetrahydrodeoxicorticosterone on rapid tolerance to the motor impairment of ethanol are depicted in Table 2. ANOVA revealed an effect for treatment with ethanol $(F(1.72)=143.92 ; p<0.001 ; F(1.72)=132.66 ;$ $p<0.001)$, for the day effect $(F(1.72)=154.86$; $p<0.001 ; F(1.72)=144.98 ; p<0.001)$ and significant pretreatment $x$ treatment $x$ day interactions $(F(1.36)=11.87$; $p<0.001 ; F(1.72)=5.33 ; p<0.001)$. The post hoc analysis suggests that pretreatment with epipregnanolone $0.15 \mathrm{mg} / \mathrm{kg}$ interferes with the blockade by allotetrahydrodeoxycorticosterone of the development of rapid tolerance to ethanol, but the pretreatment with the dose of $0.30 \mathrm{mg} / \mathrm{kg}$ did not block tolerance (Tukey' test).

In relation to the hypothermia test, the previous administration of epipregnanolone blocked the stimulant effect of pregnenolone sulfate on rapid tolerance to ethanol (Table 3). Overall, ANOVA revealed an effect for the treatment with ethanol $(F(1.72)=58.78 ; p<0.001)$, for the day factor $(F(1.72)$ $=6.98 ; p<0.001)$ and a significant pretreatment $x$ treatment $x$ day interaction $(F(1.36)=5.37 ; p<0.001)$. The post hoc analysis indicated that pretreatment with epipregnanolone 
Table 2 - Effect of epipregnanolone on the influence of neurosteroids pregnenolone sulfate, dehydroepiandrosterone sulfate and allotetrahydrodeoxycorticosterone the development of rapid tolerance to the motor impairing. Results shown are means \pm SD of 10 animals per group

\begin{tabular}{|c|c|c|c|c|c|}
\hline Treatment & & & Day 1 & Day 2 & p-value \\
\hline \multirow[t]{4}{*}{ Saline } & Saline & Saline & $13.60 \pm 4.14$ & $58.10 \pm 3.35$ & $p<0.001$ \\
\hline & & Ethanol & $57.30 \pm 9.48$ & $56.80 \pm 3.63$ & $p=0.073$ \\
\hline & PS & Saline & $12.81 \pm 6.86$ & $58.11 \pm 9.48$ & $p<0.001$ \\
\hline & & Ethanol & $61.41 \pm 6.38$ & $43.62 \pm 9.57$ & $p<0.001$ \\
\hline \multirow[t]{4}{*}{ EPI $0.15 \mathrm{mg} / \mathrm{kg}$} & Saline & Saline & $13.86 \pm 9.04$ & $57.00 \pm 12.13$ & $p<0.001$ \\
\hline & & Ethanol & $56.95 \pm 4.71$ & $55.76 \pm 9.51$ & $p=0.079$ \\
\hline & PS & Saline & $14.86 \pm 9.70$ & $58.70 \pm 8.31$ & $p<0.001$ \\
\hline & & Ethanol & $50.70 \pm 9.13$ & $35.00 \pm 8.18$ & $p=0.033$ \\
\hline \multirow[t]{4}{*}{ Saline } & Saline & Saline & $12.93 \pm 5.40$ & $58.35 \pm 4.07$ & $p<0.001$ \\
\hline & & Ethanol & $57.65 \pm 8.85$ & $57.20 \pm 3.63$ & $p=0.089$ \\
\hline & PS & Saline & $12.91 \pm 6.76$ & $58.00 \pm 9.48$ & $p<0.001$ \\
\hline & & Ethanol & $56.00 \pm 6.38$ & $44.50 \pm 9.58$ & $p=0.036$ \\
\hline \multirow[t]{4}{*}{ EPI $0.30 \mathrm{mg} / \mathrm{kg}$} & Saline & Saline & $12.60 \pm 8.31$ & $58.00 \pm 12.13$ & $p<0.001$ \\
\hline & & Ethanol & $55.90 \pm 4.71$ & $58.30 \pm 9.51$ & $p=0.095$ \\
\hline & PS & Saline & $12.00 \pm 9.70$ & $59.58 \pm 8.31$ & $p<0.001$ \\
\hline & & Ethanol & $61.56 \pm 9.123$ & $45.70 \pm 8.18$ & $p<0.001$ \\
\hline \multirow[t]{4}{*}{ Saline } & Saline & Saline & $12.96 \pm 5.37$ & $59.57 \pm 8.22$ & $p<0.001$ \\
\hline & & Ethanol & $58.92 \pm 8.22$ & $57.78 \pm 7.93$ & $p=0.069$ \\
\hline & DHEAS & Saline & $12.05 \pm 7.27$ & $59.59 \pm 9.48$ & $p<0.001$ \\
\hline & & Ethanol & $64.36 \pm 7.90$ & $44.06 \pm 5.37$ & $p<0.001$ \\
\hline \multirow[t]{4}{*}{ EPI $0.15 \mathrm{mg} / \mathrm{kg}$} & Saline & Saline & $12.77 \pm 12.96$ & $59.27 \pm 12.64$ & $p<0.001$ \\
\hline & & Ethanol & $64.50 \pm 11.69$ & $60.68 \pm 9.78$ & $p=0.071$ \\
\hline & DHEAS & Saline & $10.90 \pm 4.10$ & $55.40 \pm 7.46$ & $p<0.001$ \\
\hline & & Ethanol & $52.91 \pm 12.96$ & $48.41 \pm 13.27$ & $p<0.062$ \\
\hline \multirow[t]{4}{*}{ Saline } & Saline & Saline & $11.00 \pm 5.37$ & $59.57 \pm 8.22$ & $p<0.001$ \\
\hline & & Ethanol & $58.92 \pm 8.25$ & $57.98 \pm 7.90$ & $p=0.088$ \\
\hline & DHEAS & Saline & $12.50 \pm 7.27$ & $59.59 \pm 9.48$ & $p<0.001$ \\
\hline & & Ethanol & $64.36 \pm 7.90$ & $44.06 \pm 5.37$ & $p=0.030$ \\
\hline \multirow[t]{4}{*}{ EPI $0.30 \mathrm{mg} / \mathrm{kg}$} & Saline & Saline & $12.00 \pm 12.94$ & $59.70 \pm 12.64$ & $p<0.001$ \\
\hline & & Ethanol & $64.79 \pm 11.69$ & $62.60 \pm 9.80$ & $p=0.099$ \\
\hline & DHEAS & Saline & $11.60 \pm 12.95$ & $60.40 \pm 7.46$ & $p<0.001$ \\
\hline & & Ethanol & $61.58 \pm 3.10$ & $54.61 \pm 13.27$ & $p<0.001$ \\
\hline \multirow[t]{4}{*}{ Saline } & Saline & Saline & $11.18 \pm 9.80$ & $56.10 \pm 9.04$ & $p<0.001$ \\
\hline & & Ethanol & $61.12 \pm 8.22$ & $45.64 \pm 7.93$ & $p<0.001$ \\
\hline & ALLOT & Saline & $10.38 \pm 7.26$ & $63.66 \pm 9.48$ & $p<0.001$ \\
\hline & & Ethanol & $63.04 \pm 7.90$ & $62.76 \pm 5.37$ & $p=0.074$ \\
\hline \multirow[t]{4}{*}{$\mathrm{EPI} 0.15 \mathrm{mg} / \mathrm{kg}$} & Saline & Saline & $10.45 \pm 12.96$ & $64.80 \pm 12.64$ & $p<0.001$ \\
\hline & & Ethanol & $67.07 \pm 11.69$ & $64.10 \pm 9.80$ & $p=0.065$ \\
\hline & ALLOT & Saline & $12.50 \pm 12.95$ & $61.85 \pm 7.46$ & $p<0.001$ \\
\hline & & Ethanol & $63.23 \pm 9.79$ & $48.84 \pm 13.27$ & $p<0.001$ \\
\hline \multirow[t]{4}{*}{ Saline } & Saline & Saline & $12.18 \pm 5.37$ & $58.50 \pm 8.22$ & $p<0.001$ \\
\hline & & Ethanol & $60.20 \pm 8.85$ & $46.36 \pm 8.72$ & $p<0.001$ \\
\hline & ALLOT & Saline & $10.38 \pm 7.30$ & $63.66 \pm 9.48$ & $p<0.001$ \\
\hline & & Ethanol & $63.04 \pm 7.90$ & $62.76 \pm 5.37$ & $p=0.063$ \\
\hline \multirow[t]{4}{*}{ EPI $0.30 \mathrm{mg} / \mathrm{kg}$} & Saline & Saline & $10.60 \pm 12.95$ & $64.80 \pm 12.64$ & $p<0.001$ \\
\hline & & Ethanol & $66.80 \pm 11.69$ & $63.60 \pm 9.79$ & $p=0.069$ \\
\hline & ALLOT & Saline & $13.00 \pm 10.11$ & $62.97 \pm 7.46$ & $p<0.001$ \\
\hline & & Ethanol & $66.19 \pm 9.79$ & $55.51 \pm 13.27$ & $p<0.001$ \\
\hline
\end{tabular}

$E P I=$ Epipregnanolone. $P S=$ Pregnenolone sulfate. $D H E A S=$ Dehydroepiandrosterone sulfate. ALLOT = Allotetrahydrodeoxycorticosterone. SD = Standard deviation.

blocked the stimulatory eftect of pregnenolone sultate on the development of rapid tolerance (Tukey's test).

Similarly, the pretreatment with $0.30 \mathrm{mg} / \mathrm{kg}$ epipregnanolone before $0.20 \mathrm{mg} / \mathrm{kg}$ dehydroepiandrosterone sulfate on Day 1 resulted in blockade of the stimulant effect of dehydroepiandrosterone sulfate on rapid tolerance to ethanol (Table 3). Overall, ANOVA revealed a significant effect for the treatment with ethanol $(F(1.72)=41.41 ; p<0.001)$, for the treatment with dehydroepiandrosterone sulfate $(F(1.72)=7.26 ; p<0.001)$ and for the day effect $(F(1.72)=5.09 ; p<0.001)$. The post hoc analysis indicated that pretreatment with epipregnanolone blocked the stimulating effect of dehydroepiandrosterone sulfate on rapid tolerance (Tukey's test).
Similarly to the results obtained with the rota-rod test, the previous administration of epipregnanolone blocked the effects of allotetrahydrodeoxycorticosterone on rapid tolerance to the hypothermic effect of ethanol evaluated on Day 2 (Table 3). ANOVA revealed an effect for treatment with ethanol $(F(1.72)=44.61 ; p<0.001)$, for treatment with allotetrahydrodeoxycorticosterone $(F(1.72)=6.24$; $\mathrm{p}<0.001)$, for pretreatment with epipregnanolone ( $F(1.72)$ $=6.79 ; p<0.001)$ and significant pretreatment $x$ treatment $x$ day interactions $(F(1.36)=25.161 ; p<0.001)$. The post hoc analysis suggests that pretreatment with epipregnanolone interferes with the blockade by allotetrahydrodeoxycorticosterone of the development of rapid tolerance to ethanol (Tukey's test). 
Table 3 - Effect of epipregnanolone on the influence of neurosteroids pregnenolone sulfate, dehydroepiandrosterone sulfate and allotetrahydrodeoxycorticosterone the development of rapid tolerance to the hypothermic effect of ethanol. Results shown are means \pm $\mathrm{SD}$ of 10 animals per group

\begin{tabular}{|c|c|c|c|c|c|}
\hline Treatment & & & Day 1 & Day 2 & p-value \\
\hline \multirow[t]{4}{*}{ Saline } & Saline & Saline & $0.14 \pm 0.41$ & $1.46 \pm 0.47$ & $p<0.001$ \\
\hline & & Ethanol & $1.81 \pm 0.47$ & $1.65 \pm 0.54$ & $p=0.067$ \\
\hline & PS & Saline & $0.12 \pm 0.44$ & $1.61 \pm 0.38$ & $p<0.001$ \\
\hline & & Ethanol & $2.00 \pm 0.45$ & $0.91 \pm 0.47$ & $p<0.001$ \\
\hline \multirow[t]{4}{*}{ EPI $0.30 \mathrm{mg} / \mathrm{kg}$} & Saline & Saline & $0.23 \pm 0.25$ & $1.31 \pm 0.46$ & $p<0.001$ \\
\hline & & Ethanol & $2.00 \pm 0.50$ & $1.36 \pm 0.44$ & $p=0.084$ \\
\hline & PS & Saline & $0.20 \pm 0.41$ & $1.37 \pm 0.41$ & $p<0.001$ \\
\hline & & Ethanol & $1.78 \pm 0.42$ & $1.32 \pm 0.38$ & $p=0.079$ \\
\hline \multirow[t]{4}{*}{ Saline } & Saline & Saline & $0.10 \pm 0.41$ & $1.46 \pm 0.47$ & $p<0.001$ \\
\hline & & Ethanol & $1.85 \pm 0.35$ & $1.69 \pm 0.47$ & $p=0.061$ \\
\hline & DHEAS & Saline & $0.17 \pm 0.38$ & $1.64 \pm 0.54$ & $p<0.001$ \\
\hline & & Ethanol & $1.68 \pm 0.14$ & $0.90 \pm 0.35$ & $p<0.001$ \\
\hline \multirow[t]{4}{*}{$\mathrm{EPI} 0.30 \mathrm{mg} / \mathrm{kg}$} & Saline & Saline & $0.16 \pm 0.44$ & $1.31 \pm 0.50$ & $p<0.001$ \\
\hline & & Ethanol & $1.90 \pm 0.38$ & $1.37 \pm 0.35$ & $p=0.091$ \\
\hline & DHEAS & Saline & $0.21 \pm 0.38$ & $1.23 \pm 0.41$ & $p<0.001$ \\
\hline & & Ethanol & $1.62 \pm 0.44$ & $1.28 \pm 0.38$ & $p=0.075$ \\
\hline \multirow[t]{4}{*}{ Saline } & Saline & Saline & $0.20 \pm 0.41$ & $1.52 \pm 0.38$ & $p<0.001$ \\
\hline & & Ethanol & $1.86 \pm 0.47$ & $0.57 \pm 0.35$ & $p<0.001$ \\
\hline & ALLOT & Saline & $0.06 \pm 0.41$ & $1.25 \pm 0.44$ & $p<0.001$ \\
\hline & & Ethanol & $1.77 \pm 0.45$ & $1.21 \pm 0.38$ & $p=0.048$ \\
\hline \multirow[t]{4}{*}{ EPI $0.30 \mathrm{mg} / \mathrm{kg}$} & Saline & Saline & $0.11 \pm 0.25$ & $1.31 \pm 0.28$ & $p<0.001$ \\
\hline & & Ethanol & $1.96 \pm 0.57$ & $1.45 \pm 0.41$ & $p=0.070$ \\
\hline & ALLOT & Saline & $0.23 \pm 0.44$ & $1.55 \pm 0.37$ & $p<0.001$ \\
\hline & & Ethanol & $1.67 \pm 0.41$ & $0.68 \pm 0.38$ & $p<0.001$ \\
\hline
\end{tabular}

$E P I=$ Epipregnanolone. $P S=$ Pregnenolone sulfate. $D H E A S=$ Dehydroepiandrosterone sulfate. $A L L O T=$ Allotetrahydrodeoxycorticosterone. $S D=S t a n d a r d$ deviation.

\section{Discussion}

The results of the present study show that the pretreatment with epipregnanolone significantly blocked the development of rapid tolerance to the hypothermic and motor impairment effects of ethanol $(2.0$ and $2.25 \mathrm{~g} / \mathrm{kg}$ ) confirming our data obtained with the chronic study. ${ }^{21}$ This result agrees with the data obtained with muscimol, a GABAA receptor agonist that blocked rapid tolerance induced by ethanol. ${ }^{22}$ These data suggest that the increased GABA activity may prevent the development of rapid tolerance to ethanol.

In the present study, administration of epipregnanolone $(0.15$ and $0.30 \mathrm{mg} / \mathrm{kg}$ ) reversed the stimulatory action of dehydroepiandrosterone sulfate $(0.15 \mathrm{mg} / \mathrm{kg})$, but failed to affect the actions of pregnenolone sulfate $(0.08 \mathrm{mg} / \mathrm{kg})$ on rapid tolerance to the motor impairment caused ethanol. Moreover, pretreatment with epipregnanolone $(0.15 \mathrm{mg} / \mathrm{kg})$ prevented the inhibitory action of allotetrahydrodeoxycorticosterone $(0.10 \mathrm{mg} / \mathrm{kg})$ on tolerance development. The results obtained in the hypothermia and in the motor coordination experiments were similar. However, pretreatment with epipregnanolone $(0.15 \mathrm{mg} / \mathrm{kg})$ reversed the stimulatory action of ehydroepiandrosterone sulfate and of pregnenolone sulfate on ethanol tolerance, whereas it prevented the inhibitory action of allotetrahydrodeoxycorticosterone on tolerance development to the hypothermic effects of ethanol.

All the results of the present study were obtained with doses of neurosteroids that do not interfere with motor coordination of animals on Day 1 and do not produce any residual effects (baseline values) on Day 2. Furthermore, the effects of these neurosteroids seem to be pharmacodynamic rather than pharmacokinetic, since data from the literature showed that these drugs do not interfere with alcohol metabolism. ${ }^{21,25}$ Some studies have shown that the administration of ethanol increases plasma levels of neurosteroids. ${ }^{9,26}$ However, those studies were carried out on rats, and, to our knowledge, there are no studies showing similar effects in mice. Moreover, in our study, neurosteroids did not affect the behavior or body temperature of saline- or ethanol-treated animals on Day 1.

There is evidence that epipregnanolone is a specific antagonist at the neurosteroid site on the GABA-A receptor. ${ }^{6,27}$ In these studies, epipregnanolone competitively antagonized the potentiation of $[3 \mathrm{H}]$ flunitrazepam binding by pregnanolone and allopregnanolone in a similar manner. Other studies have shown that epipregnanolone (a partial agonist of GABA-A receptor) blocked the inhibitory action of pregnanolone (a positive modulator of GABA-A receptor) on the memory impairment produced by ethanol. ${ }^{28}$ Moreover, this neurosteroid antagonized the potentiation of GABA-induced $\mathrm{Cl}$ currents by pregnenolone. ${ }^{29}$ Our previous study showed that pretreatment with pregnenolone sulfate or with dehydroepiandrosterone sulfate prevented the inhibitory action of the GABA-A agonist muscimol on rapid tolerance to the motor impairment suggesting that a stimulatory action on tolerance by these neurosteroids could be mediated via an antagonistic interaction with the GABA-A receptor. ${ }^{22}$ Therefore, our present results are in accordance with the in vitro studies showing opposite effects for epipregnanolone and other neurosteroids. Moreover, these results agree with the notion suggested in previous investigations that negative allosteric modulators of the GABAA (pregnenolone sulfate and dehydroepiandrosterone sulfate) act non-competitively to reduce the activity of GABA-A., ${ }^{4,5}$

On the other hand, studies have shown that neurosteroids, which are positive allosteric modulators of the GABA-A receptor, can impair learning, whereas those with negative influence on this receptor system or positive allosteric modulators of the NMDA receptor can improve learning and memory in rodents. ${ }^{28-}$ 30 It was suggested that pregnenolone sulfate blocks the deficit in passive avoidance response and reduces the motor impairment induced by NMDA antagonists. ${ }^{30,31}$ Furthermore, studies have shown that pregnenolone sulfate and 
dehydroepiandrosterone sulfate also prevent the memory impairment produced by ethanol. ${ }^{28}$ Additional studies suggest that dehydroepiandrosterone sulfate modulates synaptic transmission and long-term potentiation in the CA1 region of the rat hippocampal slice. ${ }^{32,33}$ In other studies, the neurosteroids pregnenolone sulfate and dehydroepiandrosterone sulfate appear also to increase memory by acting as sigma receptor agonists, 2,34 and these neurosteroids reduce dizocilpineinduced memory impairment via the sigma-1 receptor. ${ }^{2,35,36}$ Therefore, these studies suggest that neurosteroids may play a role in the physiological regulation of GABA-A and NMDA receptor function related to memory.

An increasing body of evidence has strengthened the hypothesis that learning plays an important role in the development of tolerance to ethanol effects. It was shown that chronic tolerance to ethanol motor incoordination was facilitated when animals had the opportunity of practicing the task while intoxicated. ${ }^{37,38}$ Similarly, Bitrán and Kalant, have shown that learning plays an important role in the development of RT and acute tolerance to ethanol. ${ }^{37}$

It is well known that the GABA-A and NMDA receptor systems have been implicated in cognitive processes such as learning and memory ${ }^{39,40}$ and in the induction of different forms of synaptic plasticity, such as the long-term potentiation. ${ }^{41}$ In addition, GABAA receptor agonists and NMDA receptor antagonists impair acquisition and retention in several memory experiments, ${ }^{39,41}$ while ethanol can depress long-term potentiation. ${ }^{40}$ Additionally, studies obtained in our and other laboratories have shown that rapid tolerance to the motor incoordination and hypothermic effects produced by ethanol is stimulated and inhibited $1^{4,18-22}$ by drugs that improve and impair learning and memory, respectively. Moreover, learning contributes to rapid tolerance acquisition. ${ }^{37}$ Thus, considering that neurosteroids may act as positive or negative allosteric modulators at the GABA-A and NMDA receptors ${ }^{1,4}$ a possible explanation for the results obtained in the present study could be the influence of these neurosteroids in processes related to synaptic plasticity involving the GABA-A and the NMDA receptor systems.

Another possibility in relation to the blockade of rapid tolerance by drugs could be the occurrence of state-dependent learning. To study this possibility, Khanna et al. ${ }^{42}$ treated one group of rats with ketamine (a NMDA antagonist that blocks rapid tolerance) before ethanol on both days 1 and 2 of the experiment, and compared to another group treated with ketamine before ethanol only on day 1 . The results showed that tolerance was blocked even when ketamine was administered before ethanol on both days 1 and 2. Further, when ketamine was given before ethanol only on day 2 , it did not block the expression of rapid tolerance to ethanol. Thus, these results suggest that state-dependent learning does not seem to be a determinant factor in the development of rapid tolerance to ethanol. However, since we did not perform a similar experiment using neurosteroids, it can not be ruled out that state-dependent learning could participate in the effects of neurosteroids on rapid tolerance to ethanol.

Taken together, our results suggest a differential interaction between neurosteroids in the modulation of the development of rapid tolerance to ethanol-induced hypothermia and motor incoordination in mice. This differential modulation by neurosteroids of tolerance to ethanol may be relevant to understanding the mechanisms underlying alcoholism and may contribute to the development of potential therapeutic alternative for the treatment of ethanol dependence.

\section{References}

1. Weaver CE, Wu F-S, Gibbs TT, Farb DH. Pregnenolone sulfate exacerbates NMDA-induced death of hippocampal neurons. Brain Res. 1998;803(1-2):129-36.

2. Zou LB, Yamada K, Sasa M, Nakata Y, Nabeshima T. Effects of sigma (1) receptor agonist SA4503 and neuroactive steroids on performance in a radial arm maze task in rats. Neuropharmacology. 2000;39(9): 1617-27

3. Park-Chung M, Wu FS, Purdy RH, Malayev AA, Gibbs TT, Farb DH. Distinct sites for inverse modulation of $\mathrm{N}$-methyl-D-aspartate receptors by sulfated steroids. Mol Pharmacol. 1997;52(6):1113-23.

4. Majewska MD. Neurosteroids: endogenous bimodal modulators of the GABA-A receptor. Mechanism of action and physiological significance. Prog Neurobiol. 1992;38(4):379-95.

5. Mienville JM, Vicini S. Pregnenolone sulfate antagonizes GABA-A receptor-mediated currents via a reduction of channel opening frequency. Brain Res. 1989;489(1):190-4.

6. Prince RJ, Simmonds MA. Differential antagonism by epipregnanolone of alphaxolone and pregnanolone potentiate of $[3 \mathrm{H}]$ flunitrazepam binding suggested more than one class of binding site for steroids at GABA-A receptors. Neuropharmacology. 1993;32(1):59-63.

7. Schumacher M, McEwen BS. Steroid and barbiturate modulation of the GABA-A receptor. Possible mechanisms. Mol Neurobiol. 1989;3(4):275-304.

8. Irwin RP, Maragakis NJ, Rogawski MA, Purdy RH, Farb DH, Paul SM. Pregnenolone sulfate augments NMDA receptor- mediated increases in intracellular $\mathrm{Ca} 2+$ in cultured rat hippocampal neurons. Neurosci Lett. 1992;141(1):30-4

9. VanDoren MJ, Matthews DB, Janis CG, Grobin AC, Devaud LL, Morrow AL. Neuroactive steroid 3alpha-hydroxy-5alpha-pregnan20-one modulates electrophysiological and behavioral actions of ethanol. J Neurosci. 2000;20(5):1982-9.

10. Vanover KE, Suruki M, Robledo S, Huber M, Wieland S, Lan NC, Gee KW, Wood PL, Cater RB. Positive allosteric modulators of the GABA-A receptor, differential interaction of benzodiazepines and neuroactive steroids with ethanol. Psychopharmacology. 1999;141(1):77-82.

11. Czlonkowska A, Krzascik P, Sienkiewicz-Jarosz H, Siemiatkowski M, Szyndler J, Bidzinski A, Plaznik A. The effects of neurosteroids on picrotoxin, bicuculline and NMDA-induced seizures, and a hypnotic effect of ethanol. Pharmacol Biochem Behav. 2000;67(2):345-53.

12. Kalant $\mathrm{H}$. Current state of knowledge about the mechanisms of alcohol tolerance. Addict Biol. 1996;1(2):133-41.

13. Tabakoff B, Hellevuo K, Hoffman PL. Alcohol. In: Schuster CR, Gust SG, Kuhar MJ, editors. Handbook of experimental pharmacology: pharmacological aspects of drugs dependence. Berlin: SpringerVerlag; 1996. p. 373-458.

14. Barreto PS, Lemos T, Morato GS. NMDA-receptor antagonists block the development of rapid tolerance to ethanol in mice. Addict Biol. 1998;3:55-64.

15. Crabbe JC, Rigter H, Uijlen J, Strijbos C. Rapid development of tolerance to the hypothermic effect of ethanol in mice. J Pharmacol Exper Ther. 1979;208(1):128-33.

16. Khanna JM, Chau A, Shah G. Characterization of the phenomenon of rapid tolerance to ethanol. Alcohol. 1996;13(6):621-8.

17. Bowen $\mathrm{CA}$, Purdy RH, Grant KA. Ethanol-like discriminative stimulus effects of endogenous neuroactive steroids: effect of ethanol training dose and dosing produced. J Pharmacol Exp Ther. 1999;289(1):405-11

18. Khanna JM, Kalant H, Shah G, Chau A. Effect of (+) MK-801 and ketamine on rapid tolerance to ethanol. Brain Res Bull. 1992;28(2):311-4

19. Khanna JM, Kalant H, Shah G, Chau A. Effect of D-cycloserine on rapid tolerance to ethanol. Pharmacol Biochem Behav. 1993;45(4):983-6

20. Khanna JM, Shah G, Weiner J, Wu PH, Kalant H. Effect of NMDA antagonists on rapid tolerance to ethanol. Eur J Pharmacol $1993 ; 230(1): 23-31$ 
21. Barbosa AD, Morato GS. Effect of epipregnanolone and pregnenolone sulfate a chronic tolerance to ethanol. Pharmacol Biochem Behav. 2000;67(3):459-64.

22. Barbosa AD, Morato GS. Influence of neurosteroids on the development of rapid tolerance to ethanol in mice. Eur J Pharmacol. $2001 ; 431(2): 179-88$.

23. Zaleski MJ, Nunes-Filho JR, Lemos T, Morato GS. GABA-B receptors play a role in the development of tolerance to ethanol in mice. Psychopharmacology (Berl). 2001;153(4):415-24.

24. Barbosa AD, Morato GS. Pregnenolone sulfate, dehydroepiandrosterone sulfate and allotetrahydrodeoxicorticosterone affect rapid tolerance to the hypothermic effect of ethanol. Brain Res Bull. 2002;58(1):99-105.

25. Melchior CL, Allen PM. Interaction of pregnanolone and pregnenolone sulfate with ethanol and pentobarbital. Pharmacol Biochem Behav. 1992;42(4):605-11.

26. Barbaccia ML, Affricano D, Trabucchi M, Purdy RH, Colombo G, Agabio R, Gessa GL. Ethanol markedly increases GABAergic neurosteroids in alcohol-preferring rats. Eur J Pharmacol. 1999;384(2-3):R1-2.

27. Prince RJ, Simmonds MA. 5 beta-pregnan-3 beta-ol-20-one, a specific antagonist at the neurosteroid site of the GABAA receptorcomplex. Neurosci Lett. 1992;135(2):273-5.

28. Melchior CL, Ritzmann RF. Neurosteroids block the memoryimpairing effects of ethanol in mice. Pharmacol Biochem Behav. $1996 ; 53(1): 51-6$

29. Petty CJ, Simmonds MA. Antagonism of 5 -pregnan-3 -ol-20-on by its 3 -isomer on GABA-evoked currents in cultures neurons. Fundam Clin Pharmacol. 1991;5:384.

30. Mathis C, Paul SM, Crawley N. The neurosteroid pregnenolone sulfate blocks NMDA antagonist-induced deficits in a passive avoidance memory task. Psychopharmacology. 1994;116(2):201-6.

31. Mathis C, Vogel E, Cagniard B, Criscuolo F, Ungerer A. The neurosteroids pregnenolone sulfate blocks deficits induced by a competitive NMDA antagonist in active avoidance and lever-press learning tasks in mice. Neuropharmacology. 1996;35(8):1057-64.

32. Meyer JH, Gruol DL. Dehydroepiandrosterone sulfate alters synaptic potentials in area CA1 of the hippocampal slice. Brain Res. 1994;633(1-2):253-61.

33. Randall RD, Lee SY, Meyer JH, Wittenberg GF, Gruol DL. Acute alcohol blocks neurosteroid modulation of synaptic transmission and long-term potentiate in the hippocampal slice. Brain Res. $1995 ; 701(1-2): 238-48$.

34. Monnet FP, Mahé V, Robel P, Baulieu EE. Neurosteroids, via receptors, modulate the $[3 \mathrm{H}]$ norepinephrine release evoked by $\mathrm{N}$-methyl-Daspartate in the rat hippocampus. Proc Natl Acad Sci U S A. 1995;92(9):3774-8

35. Maurice T, Junien JL, Privat A. Dehydroepiandrosterone sulfate attenuates dizocilpine-induced learning impairment in mice via 1receptors. Behav Brain Res. 1997;83(1-2):159-64.

36. Maurice T, Roman FJ, Privat A. Modulation by neurosteroids of the in vivo (+)-[3H] SKF-10, 047 binding to 1 receptors in the mouse forebrain. J Neurosci Res. 1997;46(6):734-43.

37. Bitrán $M$, Kalant $H$. Learning factor in rapid tolerance to ethanolinduced motor impairment. Pharmacol Biochem Behav. $1991 ; 39(4): 917-22$.

38. LeBlanc AE, Gibbins RJ, Kalant $H$. Behavioral augmentation of tolerance to ethanol in the rat. Psychopharmacologia. 1973;30(2): 117-22.

39. Collingridge GL, Harvey J, Frenguelli BG, Bortolotto ZIB, Davies $\mathrm{CH}$. Amino acid receptors and long term potentiate: targets for the development of cognitive enhancers. Int Acad Biomed Drug Res. 1992;2:41-9.

40. Morrisett RA, Swartzwelder HS. Attenuation of hippocampal longterm potentiation ethanol: a patch-clamp analysis of glutamatergic and GABAergic mechanisms. J Neurosci. 1993;13(1):2264-72.

41. Morris RG, Anderson E, Lynch GS, Baudry M. Selective impairment of learning and blockade of long-term potentiation by an N-methyl-D-aspartate receptor antagonist, AP5. Nature. 1986;319(6056):774-6.

42. Khanna JM, Mihic SJ, Weiner J, Shah G, Wu PH, Kalant H. Differential inhibition by NMDA antagonists of rapid tolerance to, and cross-tolerance between, ethanol and chlordiazepoxide. Brain Res. $1992 ; 574(1-2): 251-6$. 